\title{
An Assessment of Pension Insurance on the Socio-Economic Life of the Retired Population in Buea-Cameroon
}

\author{
Abia Elisabeth Achancho \\ Catholic University Institute of Buea (CUIB), Cameroon \\ Email: aqueeneli@yahoo.fr \\ Received 9 December 2015; accepted 25 April 2016; published 28 April 2016 \\ Copyright (C) 2016 by author and Scientific Research Publishing Inc. \\ This work is licensed under the Creative Commons Attribution International License (CC BY). \\ http://creativecommons.org/licenses/by/4.0/

(c) (i) Open Access

\section{Abstract}

This work aimed at evaluating the impact of pension insurance on the socio-economic life of the retired population in Buea-Cameroon. The objectives of the study were to appraise the policies and procedures used to obtain old age pension and old age allowance, and to assess the impact of old age pension and old age allowance on the socio-economic life of the retired population in Cameroon, precisely the Buea municipality. To achieve these objectives, the researcher came out with methods of data collection which included questionnaires that were administered to respondents in Buea and interviews. The said data were analysed with the help of simple regression and it was discovered from the analyses that an increase in old age pension and old age allowance will better off the socio-economic life of the retired population. Moreover, this relationship also portrays that, a fall in old age pension and old age allowance will worsen off the socio-economic life of the retired population. From these findings, the researcher recommends that, the National Social Security Fund should be able to hold seminars and give advices to the retired population on how they could better manage their retirement income, which will enable them to meet up their standard of living and satisfy their basic necessities such as their health, children's education, feeding and many others.

\section{Keywords}

Pension, Insurance, Old Age Pension, Old Age Allowance, Retirement, Aging Population, Socio-Economic Life, Study, The Cameroon National Social Insurance Fund

\section{Introduction}

Pension insurance is defined as retirement benefit paid frequently with the amount based usually on the duration 
of employment and the amount of pay that the pensioners used to have during active service. In terms of both the number of recipients and of total expenditure, the retirement pensions are undoubtedly the most important benefit provided by the Cameroon "Social Security System" [1]. In Britain, pressure for the introduction of state owned pension began in the 1870's. The pamphlets of an Anglican clergy man, the Rev. William Blacky and of Charles Booth first drew attention to accrued poverty of many old people [2] and the inadequacy of the poor law to deal with. The call for the introduction of some state provisions was taken up by trade unions movements and the new labor party. It also attached a few liberals prominent among them being Joseph Chamberlain.

It was resisted however, by the charity organization society [3] which constantly emphasizes the unique virtues of self-help and by a friendly society worried that any contributory scheme such as that introduced in Bismarck’s Germany in 1889 will hamper their own recruitment of funds. The introduction in 1899 of a non-contributory scheme in Newzerland increased interests in proposals in a state pension. The first year, a parliamentary select committee recommended the introduction of the means-tested scheme even the friendly work incentives. The formal includes: the medical test for voluntarily leaving employment, the array of legislative provisions and administrative machinery design to protect and penalize a bus. The indirect method has been used to fix the rate of benefits so that the claimants do not loose financially by returning to work. The poor law will be recalled explicitly to adopt the principle that recipient of welfare should be worse off than those in the lowest paid employment. For example, the waged-stop rule according to which claimants were not to receive more by way of benefits than they would have earned in their normal employment not withstanding that the amount in question was below the officially recognized subsistent level.

Social welfare [4] generates profits as well as cost to aggregate welfare. For example it produces a healthier and more efficient labor force than will otherwise be the case and it helps to stabilize the economy by reducing the severity of depressions and putting a break on booms. Whatever the net losses, when these benefits have been taken into account, this must be weighed against the social value of redistribution even though it may be impossible to quantify this. There is in short a tradeoff to be made between equality and efficiency.

Societies were gradually won over to support noncontributory pensions to be financed by taxation and in 1906, Asquith the chancellor of exchequer promised to introduce old age pension [5] on this basis as soon as there was a budget surplus. The old age pension act 1908 provided for the means at a maximum of 5 shilling a week. This was payable to any one aged 70 on an annual income of less than 21 pounds a year. Persons who have been in receipt of poor relieve for the previous two years were not entitled nor were those who had recently been in prison or who had failed to maintain themselves and their dependents.

Although many aspects of the scheme appear now redundant, at least the principle was established that in certain circumstances, anyone over 70 was entitled to support from the state.

In the 1900s, pension law in its modern form was not known in Cameroon. Instead the people engaged in mutual and social undertakings. For instance in matters of agriculture, the extended family operated as a social undertaking. As product increased a farmer could call upon a whole village or group of persons notably a njangi group to work on his farm. Such groups were not paid but were treated to food and drinks as assign of gratitude or compensation for the work done. This self-reliance scheme could not keep pace with the establishment of large plantations and industries as colonization took roof. Permanent workers were being recruited and had to be paid salaries and wages. The introduction of plantations in British Cameroon came with large scale employment of workers who abandoned their own farms to work for their new employers. As these plantations were established along the coastal line, notably Victoria, this resulted in the migration of Cameroonians especially from the Bamenda hinterlands [6] to the coastal regions. These workers were only able to stay out of work during public holidays and non-working days and the employment was to last as long their work was efficient and profitable. As full time workers, remuneration was weekly, fourth nightly, or monthly. As the workers became inefficient or unprofitable, they were sent away without any compensation and the aged had to turn to their families for assistance. As a result of this hardship, a scheme was developed to cater for the welfare of workers after retirement. By this scheme, employers and employees contributed some part of their salary. This money was deducted before salaries were paid and at the end of the workers working life such money were computed and a lump sum paid back to him as retirement benefits or gratuity. Such traditional means was devised to ensure the protection of the household and the people at large against misfortune or suffering.

The first attempt in British Cameroon to draw up a beneficial pension scheme [7] was in 1922 but unfortunately it was applicable only to workers of the civil service who at this time were mainly the personnel of the national security. In fact pension was paid only to workers who held positions that were termed pensionable of- 
fices. That is those whose duties were described as such by the ordinances. It was enough to be employed to enjoy these rights. The principle on which pension was paid resulted from the interpretation of the 1922 ordinance given by the secretariat of the southern province Lagos in memorandum B 1690/1922 of 25th April 1923. The 1922 ordinance stipulated that consideration should be paid in the first place to the length of service of the official and to the manner in which he has performed his work. Efficiency above the average should be required as a condition of the grant of any allowance and the fifteen years' service mentioned in the regulation is the minimum required. So, much longer service should be required before any allowance is granted. A second consideration was the rate of the salary which had been paid to the officer in question. This had to fall within the specified index point. Thirdly the aged and physical condition of the officer was also considered. In this connection pension was paid only if the officer was too old or was handicap and so unable to obtain employment. The harshness of these conditions was watered down by secular no 2/1937M.P no 0/193P/1.2 of the government of Nigeria which stipulated that attendance should be given to ordinances No. 31 and 32 of 1936 which repeal sub Section 2 of Section 5 of the European and non-European officers pension ordinances chapter 26 and 27 respectively. Hence forth the only requirement was a recommendation from the service head once the worker attained fifty five years which was a pensionable age and this age is valid till today.

From the above analyses, the modern society drew inspiration from the traditional society insurance approach to design a scheme that affords citizens adequate social security [8]. The modern approach is codified by various international organizations, notably the 1948 universal declaration of human right and the international labor organization convention No. 102. Both instruments elevate social security [9] to the rank of universally recognized human right. These international instrument request that each state should implement a social security scheme that protect its citizens against the likely consequence of maternity, industrial accident and occupational diseases, unemployment, invalidity, sickness and death. In Cameroon, ordinance No. 73/17 of May 22, 1973 instituted a social and family protection scheme and the organization who manages this scheme is called the National Social Insurance Fund (NSIF). The National Social Insurance Fund is a public institution endowed with legal statues and financial independence and placed under the supervisory control of the Minister of Labor and Social Security. The institution's head office is in Yaounde. By virtue of article 2 of degree no 72/26 of 11 January 1974, the National Social Insurance Fund is governed by a board of directors chaired by an official of the NSIF and comprising fifteen members including workers representatives, employers representatives and government officials. The board may be dissolved by degree if it is established that there are severe irregularities relating to the management or serious professional misconduct. The NSIF is managed by a general manager and an assistant general manager both appointed by decree. The general manager ensures the execution of decisions adopted by the administrative board and can take any measure which he deems necessary for the smooth running of his services [10].

At the organizational level, the NSIF is made up of the central services located in the head quarter in Yaounde and external services spread throughout the national territory. Today the institution numbers ten (10) regional centers located in each regional headquarters of Cameroon, twelve (12) divisional centers, four (4) branches and eight (8) periodic payment centers. With this decentralization of services, the NSIF can reach out to all segments of the society and ensure adequate coverage.

The National Social Insurance Fund deals essentially with two categories of users, namely the wage earner and members of his family or rightful claimants and employers.

\section{Problem Statement}

A couple of years back, individuals, precisely the old during their young age, dedicated their energy and their life in working on their farm lands which was a source of livelihood for themselves and their families. They engaged in mutual and social undertakings, which mean that as product increased, a farmer will call upon a group of persons to work on his farm. Such groups were not paid but were treated with food and drinks as a sign of gratitude.

With the coming of industrialization, there was a shift from people working solely on their farm lands, to factories, which made people leave their homes and families to work for others. When they got old, they were sent back to their families where they depended on, for their old age. This situation created a lot of worries until pension was introduced. Even today, while some employers provide old age pension facilities to take care of the retired person at old age, other employers fail to do so. Even till date some employers with the presence of legislation, which obliges them to make provisions for registering their employees for pension insurance with the 
pension fund.

Contributing pension to the pension fund is good and will be very beneficial for the retired population. But the long procedure and policies put in place in order to receive this income after completing 180 months of work and after attaining 60 years, is a setback in our society today which goes a long way to affect the socio-economic life of the retired population.

With the coming of the pension fund, its main aim is to provide benefits to the retired populations who have been registered with it so that individuals will be able during retirement, to meet up their basic needs and maintain their economic standard of living. But some old people today during retirement and receiving pension insurance, are still unable to meet up their basic necessities such as feeding, paying their children's fees, shelter, clothing, health and many others, which is a major problem in our society today.

It is against this backdrop that the research intends to investigate the impact of pension insurance on the socio economic life of the aging population. Precisely, the old people who are retired and are receiving pension in the Buea locality. In order to assess the effect of old age pension on the retired population, the researcher poses the following research questions:

1) What are the policies and procedures put in place for the recovery of old age pension and old age allowance?

2) What is the impact of old age pension and old age allowance on the socioeconomic life of the aging population in Cameroon?

\section{Objectives of Study}

The main objective of this study is to investigate the impact of pension insurance on the socio economic life of the aging population in Buea.

To achieve this overall objective, the specific objectives of the research are:

1) To appraise the policies and procedures for the recovery of old age pension and old age allowance.

2) To analyze the impact of old age pension and old age allowance on the socioeconomic life of the aging population.

\section{Methodology}

The research design adopted for this research, was a descriptive research, which describes existing conditions or the state of a subject been studied. Here, we describe importance and the role pension insurance plays in the socio economic life of the aging population. Under this study, the researcher tries to make a description of the procedures and policies needed to be eligible and obtain pension insurance and allowance, how it can affect the socio economic life of the aging population in Cameroon. The sample size used from the study of the population, was with the help of the Purposive Random Sampling of eighty questionnaires but only sixty were responded to. Based on our study, we developed this simple linear regression model

$$
\mathrm{SEL}=\mathrm{F}(\mathrm{PA})
$$

This implies;

$$
\mathrm{SEL}=\mathrm{B}_{0}+\mathrm{B} 1 \mathrm{PA}+\mu
$$

where,

SEL = Socio-economic life of the Aging Population.

$\mathrm{PA}=$ Pension and Allowance.

$\mathrm{B}_{0}, \mathrm{~B}_{1}=$ Parameters of variables in the model.

$\mu=$ Error or Stochastic term.

The type of questionnaire used for this research was open ended and close ended. Eighty questionnaires were administered to those receiving pension and to some officials of the pension fund. Interview was carried out with the pension officials in NSIF Buea and the aging population. The research used both the primary and secondary methods of data collection. With regard to the primary method of data collection, two techniques were employed: questionnaire and interview.

With regard to questionnaire, lists of questions were structured using open ended and closed ended questions, were distributed to respondents. Questionnaires were administered to the retired people in Buea, who are receiving old age pension and old age allowance. These questionnaires were structured in a manner that requested 
for immediate and easy response. The questionnaires took into consideration their socio-demographic characteristics such as; age, sex and job before retirement. Twenty items were considered in the questionnaires which made it very reliable. Primary data was also collected through interviews. The researcher interviewed a sample population of Cameroonians in Buea. Particularly those who could not read nor write. And this provided a lot of useful information.

The methodology used for this research is quantitative technique precisely, descriptive statistics and regression analyses. This is because it will be used to compare two variables which are pension insurance and socio-economic life. Pension insurance being the independent variable and socio-economic life being the dependent variable. The method of data presentation adopted in this study is the use of tables, bar chart, pie chart, and clustered column.

\section{Data Presentation and Analysis}

\subsection{Data Presentation}

A total of 80 questionnaires were sent out and 60 were fully answered and returned from Buea. The ages of the respondents were between 60 and above, both male and female. Their sex distribution is represented in Table 1.

From Table 1 it can be analyzed that, the questionnaires were mostly filled by males than females. As seen on Table 2, $62.5 \%$ of males responded and only $37.5 \%$ of females responded, giving a total of $100 \%$.

Table 2 presents the age range of the respondents in Buea. The table shows that 80 questionnaires were administered and 45 persons fall in the range of $60-70,15$ persons in the age range of 71 and above. From the age of 71 and above, the percentage is lower because the life expectancy [11] is low. This gives a percentage total of $100 \%$.

1) Objective one: To appraise the policies and procedures for the recovery of old age pension and allowance.

This section presents results on the first objective that was to find out the policies and procedures needed, for the recovery of old age pension and old age allowance in Cameroon. This objective was studied by determining whether it is easy and less expensive to compile the documents to obtain pension, and to know whether the procedures for receiving this income is often lengthy (Table $3 \&$ Table 4).

Table 1. Sex distribution of the respondents.

\begin{tabular}{ccc}
\hline Sex & Respondents & Percentages (\%) \\
Male & 50 & $62.5 \%$ \\
Female & 10 & $37.5 \%$ \\
Total & 60 & $100 \%$ \\
\hline
\end{tabular}

Source: field survey (2015).

Table 2. Age distribution of the respondents.

\begin{tabular}{ccc}
\hline Age & Respondents & Percentages (\%) \\
\hline $60-70$ & 45 & $75 \%$ \\
71 and Above & 15 & $25 \%$ \\
Total & 60 & $100 \%$ \\
\hline
\end{tabular}

Source: field survey (2015).

Table 3. It is easy and less expensive to compile documents to obtain old age pension and old age allowance.

\begin{tabular}{ccc}
\hline Options & Pension and Allowance & Percentages \% \\
\hline Agree & 5 & $8.3 \%$ \\
Strongly agree & 4 & $6.7 \%$ \\
Disagree & 40 & $66.7 \%$ \\
Strongly disagree & 11 & $18.3 \%$ \\
Total & 60 & 100 \\
\hline
\end{tabular}

Source: field survey (2015). 
According to the respondent from Buea, $18 \%$ strongly disagree the fact that it is easy and less costly to compile the documents needed to obtain old age pension and allowance. $67 \%$ of the respondent disagree the idea that it is easy and less costly to compile the documents to obtain old age pension and old age allowance. On the other hand, $7 \%$ strongly agree that it is easy and less costly to compile the documents. Moreover, $8 \%$ agree it is easy and less costly to compile documents to obtain pension insurance and allowance (Figure 1).

According to the respondent from Buea, $12 \%$ strongly disagree the idea which says the procedure for obtaining old age pension and allowance is often lengthy. Moreover, $20 \%$ of the respondents disagree with the notion that the procedure for obtaining old age pension and allowance is lengthy. On the other hand, 25\% strongly agree that the policies and procedures needed to obtain pension insurance and allowance is long. In addition to this, $43 \%$ of the respondents agree on the idea of policies and procedures being lengthy (Figure 2).

Table 4. Procedure for obtaining old age pension and allowance is often lengthy.

\begin{tabular}{ccc}
\hline Options & Pension Allowance and & Percentages \% \\
\hline Agree & 26 & $43.3 \%$ \\
Strongly agree & 15 & $25 \%$ \\
Disagree & 12 & $20 \%$ \\
Strongly disagree & 7 & $11.7 \%$ \\
Total & 60 & $100 \%$ \\
\hline
\end{tabular}

Source: field survey (2015).

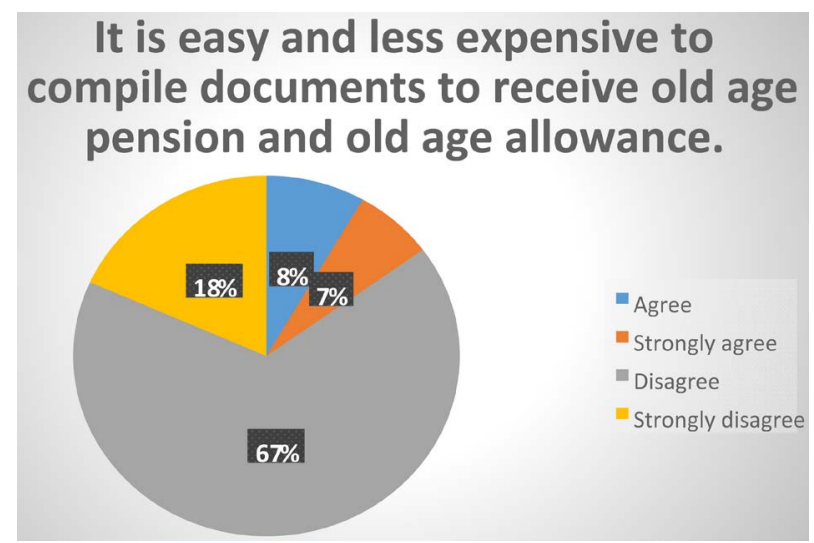

Figure 1. Graphical representation of the public's opinion on whether it is easy and less costly to compile documents to obtain old age pension or allowance.

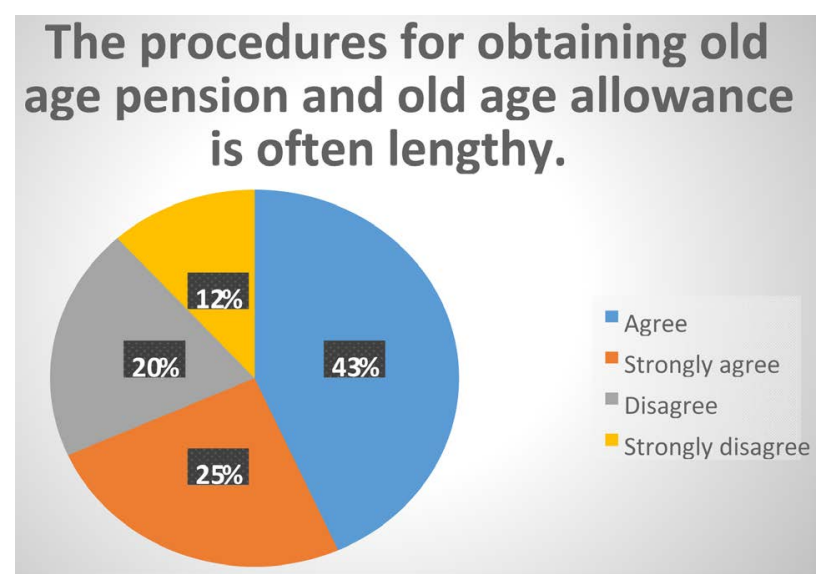

Figure 2. Graphical representation on whether the procedures for obtaining old age pension and old age allowance is lengthy. 
2) Objective two: To analyze the effect of old age pension on the socio-economic life of the aging population.

This section presents results on the second objective which is to analyze the impact of old age pension on the socio-economic life of the aging population in Buea-Cameroon. This objective was studied by determining whether old age pension has been beneficial to the aging population. In addition to this, how beneficial and useful, the income has been to the old age population (Table 5 \& Table 6).

3) The income received as old age allowance and pension is beneficial to the retired population.

Figure 3 portrays that $73.3 \%$ agree the fact that the income they receive as old age pension or allowance has been beneficial to them. On the other hand, $26.6 \%$ say, the income they receive has not been beneficial to them.

According to the respondent in Buea, $100 \%$ use their pension for their health, $82.5 \%$ use their income for their children's education. Moreover, 55\% of those receiving old age pension use the income to expand their businesses, while $37.5 \%$ use the money to start up new businesses (Figure 4).

4) Objective three: To analyze the effect of old age allowance on the socio-economic life of the aging population.

This section presents results on the second objective which is to analyze the impact of old age allowance on the socio-economic life of the aging population in Buea. This objective was studied by determining whether old

Table 5. Old age pension and allowance has been beneficial to the retired population.

\begin{tabular}{ccc}
\hline Options & Pension and Allowance & Percentages \% \\
\hline Yes & 44 & $73.3 \%$ \\
No & 16 & $26.6 \%$ \\
Total & 60 & $100 \%$ \\
\hline
\end{tabular}

Source: field survey (2015).

Table 6. How beneficial old age pension has been to the retired population.

\begin{tabular}{ccc} 
Options & Old Age Pension & Percentages \% \\
\hline Their health & 40 & $100 \%$ \\
Children's education. & 33 & $82.5 \%$ \\
Helped to expand their business & 22 & $55 \%$ \\
Helped to start up a new business & 15 & $37.5 \%$ \\
\hline
\end{tabular}

Source: field survey (2015).

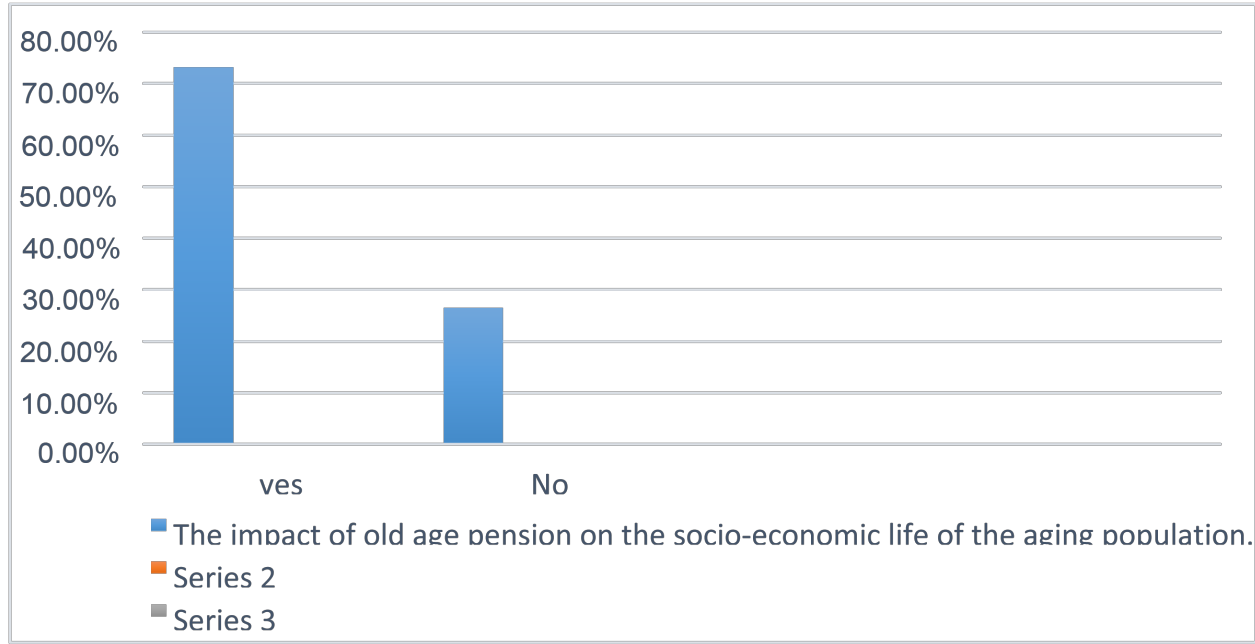

Figure 3. Graphical representation on whether the income received as old age allowance and old age pension has been beneficial to the retired population. 
age allowance has been beneficial to the aging population. In addition to this, how beneficial and useful, the income has been to the old age population (Table 7).

According to the respondent in Buea, $100 \%$ use their income for their health, $75 \%$ use their income for their children's education. Moreover, $40 \%$ of those receiving old age allowance use the income to expand their businesses, while $50 \%$ use the money to start up new businesses (Figure 5).

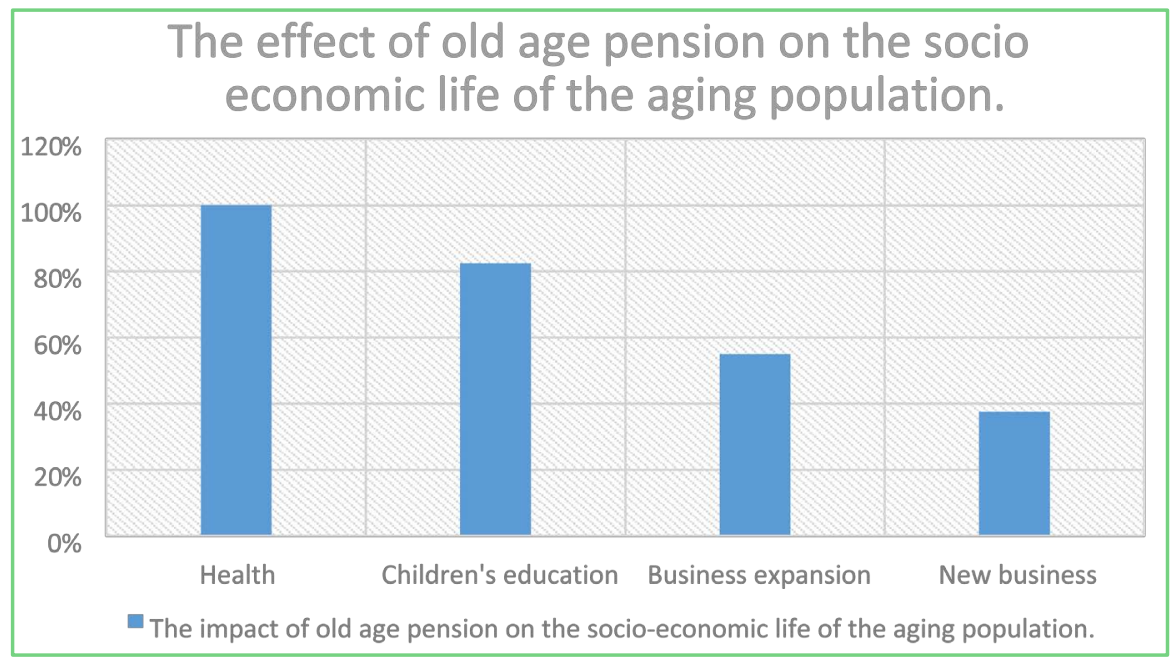

Figure 4. Graphical representation on the effect of old age pension on the socioeconomic life of the aging population.

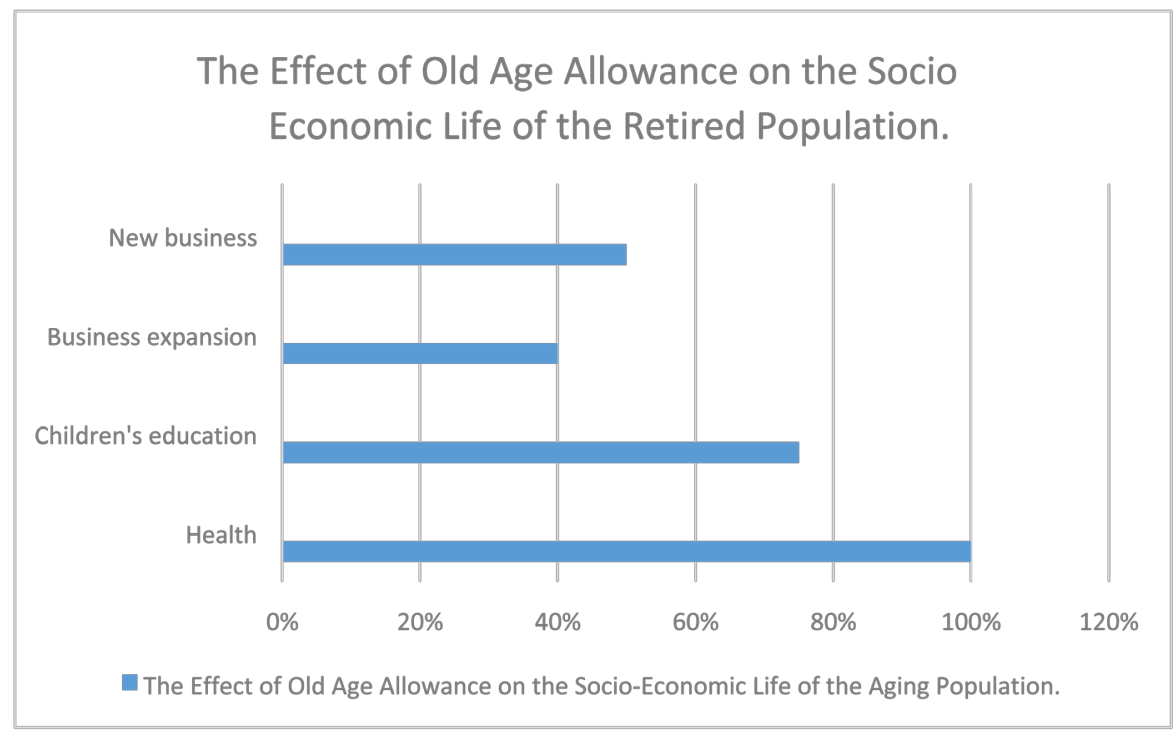

Figure 5. Graphical representation on the effect of old age allowance on the socio-economic life of the retired population.

Table 7. How beneficial old age allowance has been to the retired population.

\begin{tabular}{ccc}
\hline Options & Old Age Allowance & Percentages \% \\
\hline Their health & 20 & $100 \%$ \\
Children's education. & 15 & $75 \%$ \\
Helped to expand their business & 8 & $40 \%$ \\
Helped to start up a new business & 10 & $50 \%$
\end{tabular}

Source: field survey (2015). 


\subsection{Data Analysis}

From our regression, we notice that there are 40 observations, with the degree of freedom being 1 . The Adjusted $\mathrm{R}$ Square is 0.269678718 and the F statistics is 15.4011 . The probability of F or $\mathrm{P}>\mathrm{F}=0.0003$ (Table 8 \& Table 9).

We can notice from our regression results above that, the coefficient of old age pension and old age allowance is positive. This implies that old age pension and old age allowance has a direct relationship with the socio-economic life of the aging population. In other words, an increase in old age pension and old age allowance, will lead to an increase in the living standard of the aging population and a decrease in old age pension and old age allowance, will lead to a decrease in the living condition of the aging population.

In addition to this, we can notice that our Adjusted R Square is approximately 0.27. This means old age pension and old age allowance, accounts for $27 \%$ variability in the socio-economic life of the aging population. We can observe that our F statistics is 15.4 and $\mathrm{P}>\mathrm{F}=0.0003$. This means that the variables in our model are $99 \%$ reliable. Hence, our model best fits the regression line. This is confirmed by the F Statistics, which is significant at $5 \%$.

\section{Testing of Hypothesis}

For the purpose of this study, the hypotheses available were as follows

H0: Pension insurance has no significant effect on the socio economic life of the retired population.

H1: Pension insurance has a significant effect on the socio economic life of the retired population.

From our regression results, we observed a calculated T-Statistics of 3.924. Comparing this with our tabulated T-Statistics, thus falls between 2.021 and 2.042. We notice that the calculated T-Statistics is greater than the tabulated T-Statistics. That is, $(3.924>(2.021>\mathrm{t}<2.042))$. Therefore, we reject the null hypothesis which states that, H0; Pension insurance has no significant effect on the socio-economic life of the aging population. And accept the alternative which states, H1; Pension Insurance has a significant effect on the socio-economic life of the aging population.

\section{Discussion}

The main objective of the study was to assess the effect of pension insurance on the socio-economic life of the aging population. Now looking at this objective, it was discovered in the results that there exist a strong relationship between pension insurance and socio-economic life. This means, an increase in old age pension and old age allowance will better off the socio-economic life of the aging population. Moreover, this relationship also portrays that, a fall in old age pension and old age allowance will worsen off the socio-economic life of the aging population. Therefore, from our findings, even if it is believed that Pension insurance is very important because it has a great impact on the socio-economic life of the aging population, there are other factors which may include poverty that also affects or has an influence on the socio-economic life of the aging population. In addition

Table 8. Regression statistics.

\begin{tabular}{cc}
\hline Multiple R & Regression Statistics \\
\hline R Square & 0.53703343 \\
Adjusted R Square & 0.288404905 \\
Standard Error & 0.269678718 \\
Observations & 0.303155806 \\
\hline
\end{tabular}

Table 9. Regression results.

\begin{tabular}{|c|c|c|c|c|}
\hline Socio Economic Life & Coefficients & Standard Error & t Stat & P-value \\
\hline Intercept & 0.418045113 & 0.154027425 & 2.714095317 & 0.009936278 \\
\hline Pension and Allowance & 1.255639098 & 0.319954471 & 3.924430539 & 0.000353131 \\
\hline
\end{tabular}


to this, from our findings, we can say that the procedures for obtaining old age pension and old age allowance is lengthy and it entails a lot to compile the documents needed to obtain this income.

Compared to previous studies, failing to account for the reduction in pension wealth implies a substantial underestimation of dissaving in retirement. A number of other studies, however, have found out that to sustain life and cope with old age risk, saving including accumulating and selling assets, and storing goods for future consumption [12] is very necessary. It is important to note that most studies have tended to underestimate the degree of dissaving among "older persons" [13], because these studies have not generally accounted for the decumulation of pension wealth associated with Social Security [14] and private pension payments. Following the views of Robinson [15], the government should give opportunity for the Civic Society Organizations to provide social services to the people. This will enhance the socio-economic life of the older people and avert the old age crises [16].

One of the major limitation to this study was the unwillingness of some retired persons to respond to questionnaires. As a result, this affected the volume of data and sample size the research earlier predicted.

Pension Insurance is a very broad topic and there is need for future research in the areas of social protection of the elderly [17] in Cameroon, revision of the procedures for obtaining old age pension and old age allowance in Cameroon and the effects of pension insurance on the working population.

\section{Recommendations}

Longevity insurance should be added as a benefit provided by the Social Pension [18]. This would be another source of income available to older retirees in longevity insurance, a deferred annuity that starts at an advanced age, such as 82. This type of annuity provides a form of insurance for long-lived persons who may have out lived their non-Social Security sources of income. To do so would not only help to protect older retirees, but it would also be particularly valuable as part of a reform package that included benefit cuts. Decentralization should be done, so as to reduce the long procedures and duration to obtain retirement income and allowances. By so doing, it will reduce cost and time for the pension fund in Buea and for the retired people who are unable to leave their homes and go right to Yaoundé to follow up their documents.

\section{Conclusions}

Considering the problem statement of this research and the objectives of this study, a conclusion can be drawn that, the income that the retired population receive as old age pension and old age allowance after completing 180 months and attaining 60 years, in one way or the other, has an impact on their socio-economic life. But still, with the presence of pension insurance, some of these aging people are still unable to satisfy their basic necessities and meet up with certain standard of living. This is because, the income given as old age pension and old age allowance is relatively small, and also due to the long and costly procedure to compile the documents in order to obtain old age pension and old age allowance, also, turn to affect the socio-economic life of the aging population.

The National Social Security Fund should be able to hold seminars and give advice to the retired population on how they could better manage their retirement income, which will enable them to meet up their standard of living and satisfy their basic necessities such as, their health, children's education, feeding and many others.

The law which states that the maximum amount that a retired person can receive as pension which is 300,000 frs cfa, serving as a basis for deducting social contributions of the pension branch, no matter the number of years one contributes pension insurance and the amount one has as salary, should be ratified.

To reduce poverty and to maintain a high standard of living at retirement, most people during their working life and contributing pension to the fund, should save more [19], invest more, in other to be able to sustain a high living standard and meet up their necessities during retirement.

Old age pension and old age allowance should be increased. This means that the fixed percentage, which is usually $30 \%$, used to calculate one's average monthly wage to be received as pension, should be increased, and that a progressive percentage system should be adopted. That is, those earning low income as salary, their pension should be calculated at $40 \%$. While those earn very high income as salary, their percentages should be maintained at $30 \%$.

\section{References}

[1] Jutting, J. (2000) Social Security Systems in Low-Income Countries: Concepts, Constraints and the Need for Cooperation. International Social Security Review, 53, 3-24. http://dx.doi.org/10.1111/1468-246X.00102 
[2] HelpAge International (2002) How Social Pensions Can Deliver Effective Aid to Poor Older People.

[3] Sagner, A. and Mtati, R. (1999) Politics of Pension Sharing in Urban South Africa. Ageing and Society, 19, 393-416. http://dx.doi.org/10.1017/S0144686X99007424

[4] Adesina, J. (1997) Social Policy in Sub-Saharan African Context: In Search of Inclusive Development. Palgrave/ UNRISD, New York.

[5] HelpAge International (2005) The Mark of Noble Society: Human Rights and Older People.

[6] Njong, J. (2004) Poverty among the Elderly in Cameroon. Bamenda, Cameron.

Palacios, R.J. and Rajan, I. (2004) Safety Nets for the Elderly in Poor Countries: The Case of Nepal. Draft, The World Bank.

[7] Gillion, C. (2000) The Development and Reform of Social Security Pensions: The Approach of the International Labor Office. International Security Review, 53, 35-63. http://dx.doi.org/10.1111/1468-246X.00062

[8] Plateau, J.P. (1991) Traditional Systems of Social Security and Hunger Insurance: Past achievements and Modern Challenges. Clarendon, Oxford.

[9] World Bank (2000) Pension and Social Security in Sub Saharan Africa. World Bank, Washington DC.

[10] CNPS, National Social Insurance (2003) Social Security in Cameroon. CNPS, Yaoundé.

[11] Kinsella, K. and Velkoff, V.A. (2001) An Aging World 2001. Series P95/01-1, US Census Bureau, Washington DC.

[12] Alderman, H. and Paxson, C. (1995) Do the Poor Insure? A Synthesis of the Literature on Risk and Consumption in Developing Countries. In: Bacha, E., Ed., Economics in a Changing World, St Martins, New York, 48-78.

[13] HelpAge International (2000) Poverty and Ageing.

[14] Holzman, R. (2000) The World Bank Approach to Pension Reform. International Social Security Review, 53, 11-34. http://dx.doi.org/10.1111/1468-246X.00061

[15] Robinson, M. and White, G. (1997) The Role of Civic Organization in the Provision of Social Service: Towards Synergy. World Institute for Development Economics Research, Helsinki.

[16] World Bank (1994) Averting the Old Age Crises. World Bank, Washington DC.

[17] ILO (1992) The ILO and the Elderly. ILO, Geneva.

[18] HelpAge International (2006) Why Social Pensions Are Needed Now.

[19] Prime Ministry (2003) How to Eradicate Poverty in Cameroon. Prime Ministry, Yaounde. 